\title{
Effects of withdrawal of copper sulphate from the diet of the mature domestic fowl with special reference to production and tissue mineral content
}

\author{
BY MARY H. STEVENSON AND N. JACKSON \\ Agricultural and Food Chemistry Research Division, Department of Agriculture for Northern \\ Ireland, and the Queen's University of Belfast, Newforge Lane, Belfast BT9 $5 P X$, \\ Northern Ireland
}

(Received 12 September 1979 - Accepted 26 November 1979)

I. Cereal-based diets containing 0, 500, 1000 or $2000 \mathrm{mg}$ added copper/kg were offered ad lib. to laying hens for 8 weeks. All the hens were subsequently offered the control diet (no added $\mathrm{Cu}, 7.5 \mathrm{mg} \mathrm{Cu} / \mathrm{kg}$ ).

2. Hens from each treatment were killed at $0,2,4,6$ and 8 weeks after removal of the Cu-supplemented diets. Records were kept of body-weight, food consumption and egg production.

3. After slaughter, blood haemoglobin, packed cell volume, serum $\mathrm{Cu}$ and aspartate aminotransferase (AAT; EC 2.6.I.1) were assayed. The liver, kidneys, oviduct, ovary, gizzard, caeca and bile duct were weighed.

4. Mean $\mathrm{Cu}$, zinc and iron concentration of liver, kidneys and caecal contents were determined.

5. The adverse effects of $\mathrm{Cu}$ on body-weight, food intake, egg production and liver, oviduct, ovary, gizzard and bile weights were rapidly reversed by removal of added $\mathrm{Cu}$ from the diets.

6. Greatly enhanced liver $\mathrm{Cu}$ concentration resulted from feeding the high-Cu diets but this effect was rapidly reversed on removal of added $\mathrm{Cu}$ from the diets. Liver Fe concentration showed a less marked but similar effect.

7. The $\mathrm{Cu}$ concentration of caecal contents was increased by $\mathrm{Cu}$ supplementation and rapidly reduced after withdrawal of the Cu-containing diets.

The effects of feeding diets supplemented with copper sulphate on the performance and the mineral content of some tissues of the laying hen have been studied in this Department for some years (Jackson, 1977; Jackson et al. 1979; Stevenson \& Jackson, 1980).

Stevenson \& Jackson (1980) studied the rate at which the performance of laying hens, in terms of egg production and body-weight change and the mineral content of some specific tissues, was affected by up to $2000 \mathrm{mg}$ added copper (as $\left.\mathrm{CuSO}_{4}\right) / \mathrm{kg}$ diet. Body-weight loss, which occurred at 500-2000 $\mathrm{mg}$ added $\mathrm{Cu} / \mathrm{kg}$ diet, was apparent after only $3 \mathrm{~d}$ of Cu treatment. Egg production was depressed by high levels of added $\mathrm{Cu}$ and length of time on the $\mathrm{Cu}$-containing diets. Liver, kidney, oviduct and ovary fresh weights were depressed by $\mathrm{Cu}$ in the diet and length of time on the diets.

The liver $\mathrm{Cu}$ concentration was increased by dietary $\mathrm{Cu}$ level and length of time on the diet. The two highest levels of $\mathrm{Cu}$ addition ( 1000 and $2000 \mathrm{mg} \mathrm{Cu} / \mathrm{kg} \mathrm{diet}$ ) increased liver zinc and iron concentrations.

The present experiment was carried out in order to study the effects of the withdrawal of different levels of added $\mathrm{CuSO}_{4}$ from the diet of mature, female, domestic fowl on egg production, body-weight change and the mineral content of some tissues.

\section{EXPERIMENTAL}

White light hybrid (Shaver 288) (100, I 8 weeks old) pullets were placed in galvanized-Fe cages fitted with individual feeders and nipple drinkers. Initially the lighting programme was $1 \mathrm{I} h$ light and $13 \mathrm{~h}$ darkness and this was altered by $1 \mathrm{~h} /$ week to $17 \mathrm{~h}$ light and $7 \mathrm{~h}$ 
Table I. Mean weekly body-weight change, food intake and egg number of mature, female domestic fowl after withdrawal of Cu-supplemented diets

(Mean values for five observations)

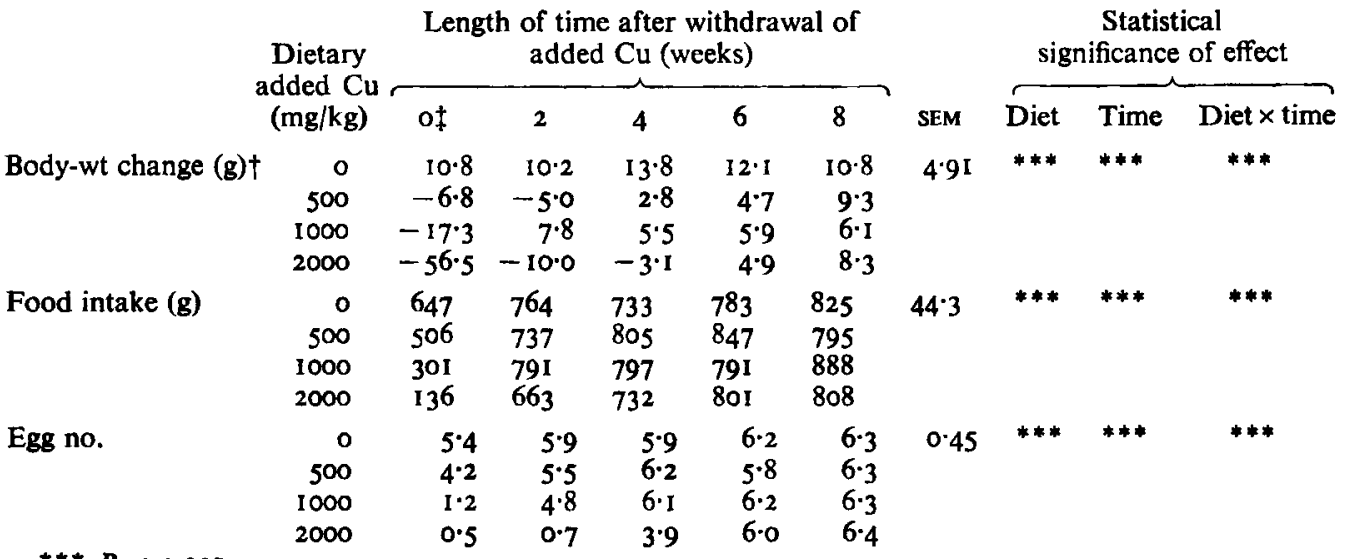

$* * * P<0.001$.

$\dagger \frac{\text { Slaughter weight - initial weight }}{\text { Total time on experiment }}$ (food intake and egg no. calculated in a similar manner).

$\ddagger$ Time 0 refers to the end of the initial eight-week feeding period.

darkness at 24 weeks and this maintained throughout the experiment. At 24 weeks of age, when all the hens had been laying for at least 2 weeks, they were randomly allocated to one of four treatment groups. The treatments were the control diet as described by Jackson (1977), and this diet to which was added 500,1000 or $2000 \mathrm{mg} \mathrm{Cu} / \mathrm{kg}$. The $\mathrm{Cu}$ was added as $\mathrm{CuSO}_{4} \cdot 5 \mathrm{H}_{2} \mathrm{O}$ the fineness of grinding of which has already been reported (Jackson, 1977). The control diet contained $(/ \mathrm{kg}): 165 \mathrm{~g}$ crude protein (nitrogen $\times 6.25), 7.5 \mathrm{mg} \mathrm{Cu}$, $95 \mathrm{mg} \mathrm{Zn}, 138 \mathrm{mg} \mathrm{Fe}, 32 \mathrm{~g}$ calcium, $5.2 \mathrm{~g}$ phosphorus and had a calculated metabolizable energy content of $I_{1} \cdot 4 \mathrm{MJ} / \mathrm{kg}$. The diets were offered $a d$ lib. for 8 weeks. At the end of this time, five birds from each treatment were randomly selected and killed by decapitation. The remaining birds from each treatment were then offered the control diet ad lib. for another 8 weeks. Five hens from each treatment were killed 2, 4, 6 and 8 weeks after placing all the birds on the control diet.

Body-weights were recorded at the start of the experiment, after 8 weeks on the control and $\mathrm{Cu}$-supplemented diets and at two-weekly intervals after withdrawal of the diets containing added $\mathrm{Cu}$. Egg production and food intake were recorded. Blood and blood serum were analysed and organs removed and examined as described by Stevenson \& Jackson (1980), except that histological examination of tissues was not carried out. In addition, the caeca and bile ducts were excised and weighed. Caecal contents were removed and a portion taken for $\mathrm{Cu}$ analysis. The weights of the empty caeca were recorded.

The methods of chemical and statistical analyses have been described by Stevenson \& Jackson (1980).

\section{RESULTS}

Mean weekly body-weight change, food intake and egg numbers are presented in Table $\mathrm{I}$. The $\mathrm{Cu}$ supplementation for 8 weeks resulted in significant weight losses and depressed food intake and egg production (all $P<0.001$ ). After 2 weeks on the control diet significant food intake differences were no longer apparent. By 6 weeks on the control diet body-weight and egg number differences were no longer significant. 
Table 2. Mean packed cell volume (PCV), serum copper and aspartate aminotransferase (AAT; EC 2.6.1.1) of mature, female domestic fowl after withdrawal of Cu-supplemented diets

(Mean values for five observations)

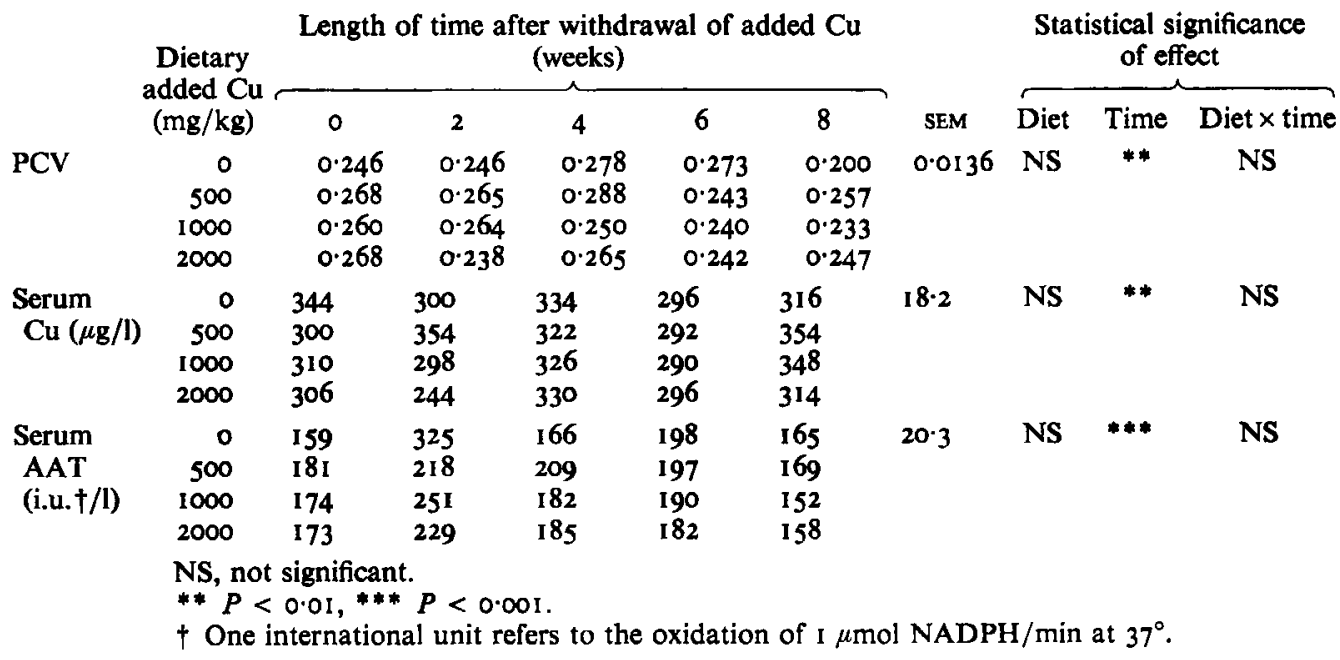

Table 3. Mean fresh weights ( $\mathrm{g} / \mathrm{kg}$ body-weight) of liver, oviduct, ovary, gizzard and bile duct together with the lipid content ( $\mathrm{g} / \mathrm{kg}$ dry matter) of the livers of mature, female domestic fowl after withdrawal of $\mathrm{Cu}$-supplemented diets

(Mean values for five observations)

\begin{tabular}{|c|c|c|c|c|c|c|c|c|c|c|}
\hline & \multirow{2}{*}{$\begin{array}{c}\text { Dietary } \\
\text { added Cu } \\
\text { (mg/kg) }\end{array}$} & \multicolumn{5}{|c|}{$\begin{array}{c}\text { Length of time after withdrawal of } \\
\text { added } \mathrm{Cu} \text { (weeks) }\end{array}$} & \multicolumn{4}{|c|}{$\begin{array}{c}\text { Statistical } \\
\text { significance of effect }\end{array}$} \\
\hline & & 0 & 2 & 4 & 6 & 8 & SEM & Diet & Time & Diet $x$ time \\
\hline Liver & $\begin{array}{r}0 \\
500 \\
1000 \\
2000\end{array}$ & $\begin{array}{l}21 \cdot 8 \\
19 \cdot 3 \\
16 \cdot 7 \\
12.6\end{array}$ & $\begin{array}{l}24 \cdot 3 \\
27 \cdot 4 \\
20 \cdot 9 \\
23 \cdot 4\end{array}$ & $\begin{array}{l}24 \cdot 2 \\
25 \cdot 7 \\
22 \cdot 7 \\
25 \cdot 3\end{array}$ & $\begin{array}{l}22 \cdot 8 \\
26 \cdot 6 \\
29 \cdot 3 \\
22 \cdot 3\end{array}$ & $\begin{array}{l}24 \cdot 5 \\
24 \cdot 6 \\
24 \cdot 3 \\
21 \cdot 8\end{array}$ & $I .65$ & $* *$ & $* * *$ & * \\
\hline Oviduct & $\begin{array}{r}0 \\
500 \\
1000 \\
2000\end{array}$ & $\begin{array}{r}40 \cdot 5 \\
28 \cdot 7 \\
27 \cdot 6 \\
2 \cdot 7\end{array}$ & $\begin{array}{l}37 \cdot 2 \\
37 \cdot 2 \\
30 \cdot 5 \\
27 \cdot 6\end{array}$ & $\begin{array}{l}32 \cdot 7 \\
34 \cdot 0 \\
38 \cdot 6 \\
30 \cdot 0\end{array}$ & $\begin{array}{l}37 \cdot 8 \\
40 \cdot I \\
38 \cdot 9 \\
34 \cdot 6\end{array}$ & $\begin{array}{l}34 \cdot 3 \\
38 \cdot 1 \\
35 \cdot 3 \\
30 \cdot 4\end{array}$ & 3.09 & $* * *$ & $* * *$ & $* * *$ \\
\hline Ovary & $\begin{array}{r}0 \\
500 \\
1000 \\
2000\end{array}$ & $\begin{array}{r}31 \cdot 7 \\
23 \cdot 7 \\
24 \cdot 4 \\
4 \cdot 2\end{array}$ & $\begin{array}{l}32 \cdot 1 \\
30 \cdot 7 \\
30 \cdot 2 \\
25 \cdot 4\end{array}$ & $\begin{array}{l}26 \cdot 3 \\
33 \cdot 9 \\
27 \cdot 0 \\
27 \cdot 5\end{array}$ & $\begin{array}{l}27 \cdot 9 \\
39 \cdot 5 \\
32 \cdot 7 \\
35 \cdot 3\end{array}$ & $\begin{array}{l}25 \cdot 6 \\
30 \cdot 7 \\
29 \cdot 4 \\
25 \cdot 2\end{array}$ & 3.97 & * & $* * *$ & * \\
\hline Gizzard & $\begin{array}{r}0 \\
500 \\
1000 \\
2000\end{array}$ & $\begin{array}{l}12 \cdot 2 \\
14.9 \\
16 \cdot 1 \\
23 \cdot 1\end{array}$ & $\begin{array}{l}12 \cdot 7 \\
15 \cdot 1 \\
13 \cdot 0 \\
14.3\end{array}$ & $\begin{array}{l}10 \cdot 6 \\
12 \cdot 3 \\
13 \cdot 3 \\
13 \cdot 7\end{array}$ & $\begin{array}{l}12.7 \\
13.5 \\
14.0 \\
13.2\end{array}$ & $\begin{array}{l}12 \cdot 0 \\
13 \cdot 0 \\
13 \cdot 2 \\
12 \cdot 3\end{array}$ & 0.80 & $* * *$ & $* * *$ & $* * *$ \\
\hline Bile duct & $\begin{array}{r}0 \\
500 \\
1000 \\
2000\end{array}$ & $\begin{array}{l}0.67 \\
1 \cdot 17 \\
1 \cdot 19 \\
1 \cdot 79\end{array}$ & $\begin{array}{l}1.22 \\
1.00 \\
1.82 \\
1.96\end{array}$ & $\begin{array}{l}I \cdot 57 \\
0.87 \\
I \cdot I 2 \\
I \cdot 14\end{array}$ & $\begin{array}{l}1 \cdot 27 \\
I \cdot 44 \\
1 \cdot 45 \\
I \cdot 44\end{array}$ & $\begin{array}{l}0.95 \\
0.84 \\
0.96 \\
1 \cdot 12\end{array}$ & 0.238 & - & $*$ & NS \\
\hline Liver lipid & $\begin{array}{r}0 \\
500 \\
1000 \\
2000\end{array}$ & $\begin{array}{l}223 \cdot 3 \\
272 \cdot 1 \\
158 \cdot 4 \\
114 \cdot 6\end{array}$ & $\begin{array}{l}304 \cdot 5 \\
285 \cdot 9 \\
211 \cdot 6 \\
271 \cdot 3\end{array}$ & $\begin{array}{l}367 \cdot 7 \\
426 \cdot 0 \\
183.8 \\
319 \cdot 2\end{array}$ & $\begin{array}{l}325 \cdot 4 \\
344 \cdot 8 \\
350 \cdot 5 \\
255 \cdot 8\end{array}$ & $\begin{array}{l}394 \cdot 0 \\
383 \cdot 9 \\
372 \cdot 4 \\
422 \cdot 9\end{array}$ & $51 \cdot 61$ & $*$ & $* * *$ & NS \\
\hline
\end{tabular}


Table 4. The mean concentrations of copper ( $\mu \mathrm{g} / \mathrm{g}$ dry matter) in the liver, kidneys and caecal contents of mature, female domestic fowl after withdrawal of Cu-supplemented diets

(Mean values for five observations)

\begin{tabular}{|c|c|c|c|c|c|c|c|c|c|c|}
\hline & \multirow{2}{*}{$\begin{array}{c}\text { Dietary } \\
\text { added Cu } \\
(\mathrm{mg} / \mathrm{kg})\end{array}$} & \multicolumn{5}{|c|}{$\begin{array}{l}\text { Length of time after withdrawal of added } \mathrm{Cu} \\
\text { (weeks) }\end{array}$} & \multirow[b]{2}{*}{ SEM } & \multicolumn{3}{|c|}{$\begin{array}{c}\text { Statistical } \\
\text { significance of effect }\end{array}$} \\
\hline & & o & 2 & 4 & 6 & 8 & & Diet & Time & Diet $\times$ time \\
\hline $\begin{array}{c}\text { Liver } \\
\mathrm{Cu} \dagger\end{array}$ & $\begin{array}{r}0 \\
500 \\
1000 \\
2000\end{array}$ & $\begin{array}{c}12 \cdot 9 \\
(I \cdot 109) \\
38 \cdot 4 \\
(1 \cdot 584) \\
822 \\
(2 \cdot 915) \\
1726 \\
(3.237)\end{array}$ & $\begin{array}{l}8.8 \\
(0.946) \\
10.6 \\
(1.019) \\
67.5 \\
(1.829) \\
284.4 \\
(2.454)\end{array}$ & $\begin{array}{l}7 \cdot 9 \\
(0 \cdot 895) \\
9 \cdot 4 \\
(0 \cdot 971) \\
19 \cdot 2 \\
(1 \cdot 284) \\
48 \cdot 7 \\
(1 \cdot 687)\end{array}$ & $\begin{array}{l}9 \cdot 9 \\
(0.986) \\
9 \cdot 8 \\
(0.992) \\
8 \cdot 9 \\
(0 \cdot 948) \\
20 \cdot 9 \\
(1 \cdot 321)\end{array}$ & $\begin{array}{l}9 \cdot 1 \\
(0.960) \\
10 \cdot 7 \\
(1 \cdot 031) \\
13 \cdot 8 \\
(1 \cdot 140) \\
14.6 \\
(1 \cdot 165)\end{array}$ & $(0.0955)$ & $* * *$ & $* * *$ & $* * *$ \\
\hline $\begin{array}{l}\text { Kidney } \\
\mathrm{Cu}\end{array}$ & $\begin{array}{r}0 \\
500 \\
1000 \\
2000\end{array}$ & $\begin{array}{l}15.6 \\
13.9 \\
15.6 \\
22.7\end{array}$ & $\begin{array}{l}11.8 \\
12.2 \\
13.0 \\
13.4\end{array}$ & $\begin{array}{l}12.0 \\
12.6 \\
12.4 \\
13.4\end{array}$ & $\begin{array}{l}17 \cdot 6 \\
14.6 \\
14 * 3 \\
18 \cdot 2\end{array}$ & $\begin{array}{l}12.2 \\
14.9 \\
15.7 \\
12.0\end{array}$ & $1 \cdot 48$ & NS & $* * *$ & * \\
\hline $\begin{array}{l}\text { Caecal } \\
\text { contents } \\
\text { Cu }{ }^{\dagger} .\end{array}$ & $\begin{array}{r}0 \\
500 \\
1000 \\
2000\end{array}$ & $\begin{array}{c}550 \\
(2 \cdot 740) \\
8851 \\
(3.947) \\
19680 \\
(4 \cdot 294) \\
13770 \\
(4.139)\end{array}$ & $\begin{array}{c}156 \\
(2 \cdot 192) \\
236 \\
(2 \cdot 372) \\
262 \\
(2 \cdot 419) \\
305 \\
(2 \cdot 484)\end{array}$ & $\begin{array}{c}15 I \\
(2 \cdot 178) \\
316 \\
(2 \cdot 500) \\
197 \\
(2 \cdot 294) \\
279 \\
(2 \cdot 445)\end{array}$ & $\begin{array}{c}148 \\
(2 \cdot 170) \\
180 \\
(2 \cdot 254) \\
151 \\
(2 \cdot 178) \\
142 \\
(2 \cdot 152)\end{array}$ & $\begin{array}{l}286 \\
(2 \cdot 456) \\
221 \\
(2 \cdot 344) \\
287 \\
(2 \cdot 458) \\
299 \\
(2 \cdot 475)\end{array}$ & $(0.0597)$ & $* * *$ & $* * *$ & $* * *$ \\
\hline
\end{tabular}

NS, not significant.

$* P<0.05, \quad * * * P<0.001$.

$\dagger$ Analysis of variance carried out using log transformations. The mean values presented are the antilogs of the mean of the $\log$ transformations. The values in parentheses are the means of the $\log$ values.

The blood measurements are shown in Table 2. Cu supplementation and withdrawal did not significantly affect haemoglobin ( $\mathrm{Hb}$ ), packed cell volume (PCV), serum $\mathrm{Cu}$ or serum aspartate aminotransferase (AAT; $E C$ 2.6.1. I). Length of time after withdrawal of the Cu-supplemented diets significantly affected PCV, serum $\mathrm{Cu}$ (both $P<0.01$ ) and AAT $(P<0.00 \mathrm{I})$ but there was no obvious trend in the effects produced. The over-all mean ( \pm SEM) Hb concentration was $78 \cdot 1 \pm 1 \cdot 02 \mathrm{~g} / \mathrm{l}$.

The mean fresh weights of liver, oviduct, ovary, gizzard and bile duct, expressed as $\mathrm{g} / \mathrm{kg}$ body-weight, together with the lipid content of the livers are given in Table 3. Cu supplementation markedly reduced liver fresh weights expressed as $\mathrm{g} / \mathrm{kg}$ body-weight. Withdrawal of the 500 and $2000 \mathrm{mg}$ added $\mathrm{Cu} / \mathrm{kg}$ diet for 2 weeks resulted in an increase in liver weight per unit body-weight $(P<0.0$ I and 0.00 I respectively). By 4 weeks, no significant differences between treatments were observed. There was a diet $\times$ time interaction $(P<0.05)$.

$\mathrm{Cu}$ supplementation markedly reduced oviduct and ovary weight $/ \mathrm{kg}$ body-weight compared with the control birds. Subsequent feeding of the control diet to all groups resulted in a rapid and significant increase in oviduct and ovary weight $/ \mathrm{kg}$ body-weight (both $P<0.001)$. Both showed a diet $\times$ time interaction.

Gizzard fresh weight (g/kg body-weight) was significantly affected by diet and time and there was a diet $\times$ time interaction (all $P<0.00$ I). The effect of increasing Cu supplementation of the diet on gizzard weight per unit body-weight was obvious at all $\mathrm{Cu}$ levels, the weight increase on $2000 \mathrm{mg} \mathrm{Cu} / \mathrm{kg}$ being approximately $90 \%$ compared to the control. The mean bile duct weight $/ \mathrm{kg}$ body-weight was significantly increased by the highest level 
Table 5. The total copper content $(\mu \mathrm{g})$ of the liver, kidneys and caecal contents of mature, female domestic fowl after withdrawal of Cu-supplemented diets

(Mean values for five observations)

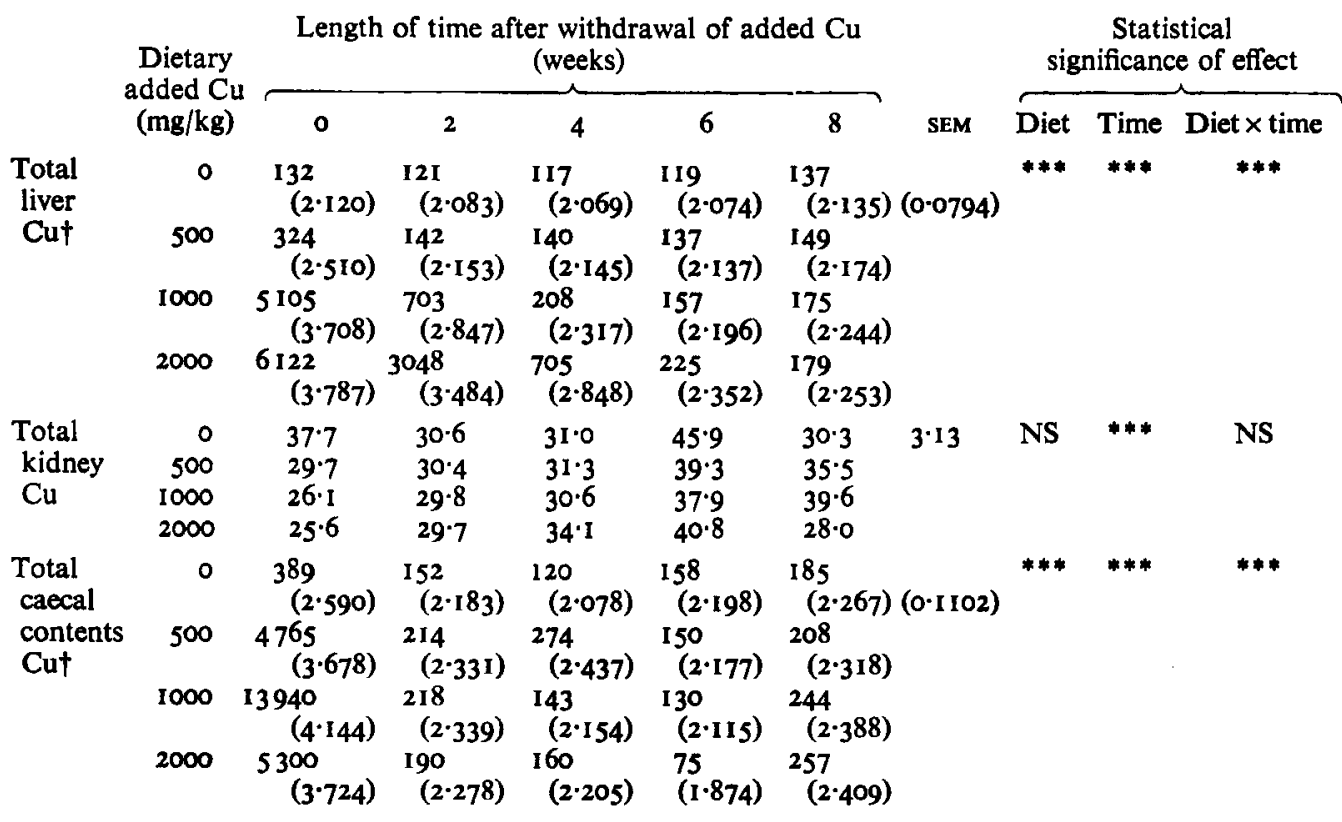

NS, not significant.

*** $P<0.001$.

$\dagger$ Analysis of variance carried out using log transformations. The mean values presented are the antilogs of the mean of the log transformations. The values in parentheses are the means of the log values.

of $\mathrm{Cu}$ supplementation and decreased by the length of time after withdrawal of these diets (both $P<0.05$ ). Caecal and kidney weights, expressed as $\mathrm{g} / \mathrm{kg}$ body-weight, were unaffected by both diet and time, the over-all mean weights ( \pm SEM) being $2 \cdot 99 \pm 0.057$ and $6 \cdot 2 \pm 0.09$ $\mathrm{g} / \mathrm{kg}$ body-weight respectively.

Liver lipid concentration (Table 3) was decreased by the two highest levels of $\mathrm{Cu}$ supplementation of the diet $(P<0.05)$. After withdrawing the $\mathrm{Cu}$-supplemented diets for 2 weeks, lipid concentration increased and this trend continued up to 8 weeks.

The concentrations and total $\mathrm{Cu}$ present in the liver, kidneys and caecal contents are shown in Tables 4 and 5 respectively. The Cu-supplemented diets offered for the initial 8 weeks caused a highly significant increase in liver $\mathrm{Cu}$ concentration while the control birds fed on the basal diet throughout the experiment were unaffected. Replacement of the $\mathrm{Cu}$ containing diets by the control diet caused a significant decrease $(P<0.00 \mathrm{I})$ in the liver $\mathrm{Cu}$ concentration after 2 weeks. By 8 weeks the differences between treatments were not significant.

The total $\mathrm{Cu}$ content of the livers of hens (Table 5) given $\mathrm{Cu}$-supplemented diets was significantly higher $(P<0.001)$ than that of hens given the control diet. After 2 weeks withdrawal of the $\mathrm{Cu}$-supplemented diets the hens which had been offered the $\mathrm{Cu}$-containing diets showed a significant reduction in total liver $\mathrm{Cu}$. The trends in the total liver $\mathrm{Cu}$ content for the remainder of the experiment generally paralleled those for liver $\mathrm{Cu}$ concentrations.

Both kidney $\mathrm{Cu}$ concentration and total kidney $\mathrm{Cu}$ content were unaffected by dietaryadded $\mathrm{Cu}$ although the mean values for $\mathrm{Cu}$ concentration suggest that feeding $2000 \mathrm{mg}$ 
Table 6. The zinc and iron concentrations ( $\mu \mathrm{g} / \mathrm{g}$ dry matter) of the liver and kidneys of mature, female domestic fowl after withdrawal of Cu-supplemented diets

(Mean values for five observations)

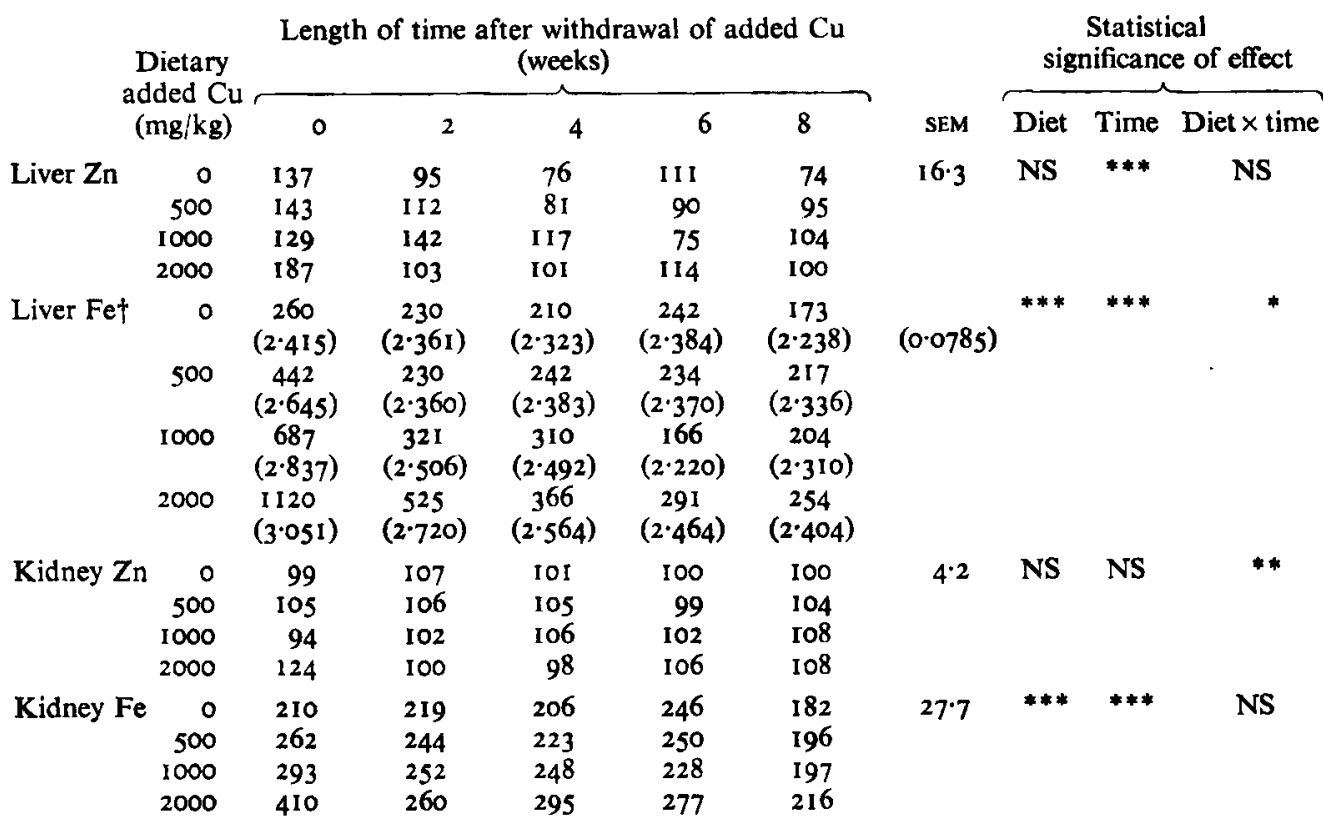

NS, not significant.

* $P<0.05, \quad * * P<0.01, \quad * * * P<0.001$.

$\uparrow$ Analysis of variance carried out using $\log$ transformations. The mean values presented are the antilogs of the mean of the log transformations. The values in parentheses are the means of the log values.

added $\mathrm{Cu} / \mathrm{kg}$ diet for 8 weeks did result in increased kidney $\mathrm{Cu}$ concentration. After 2 weeks withdrawal of added $\mathrm{Cu}$, kidney $\mathrm{Cu}$ concentration had significantly decreased $(P<0.00 \mathrm{I})$ in these birds. Over all the total kidney $\mathrm{Cu}$ content was increased with time $(P<0.001)$, showing a maximum at 6 weeks.

Feeding the $\mathrm{Cu}$-supplemented diets significantly increased the concentrations and total $\mathrm{Cu}$ of the caecal contents (Tables 4 and 5) compared with control hens $(P<0.00 \mathrm{I})$. After imposing the control diet on all groups of hens the decreases in the $\mathrm{Cu}$ concentrations and total $\mathrm{Cu}$ of caecal contents were significantly different $(P<0.001)$ compared to the levels found after the initial 8 week period.

The $\mathrm{Zn}$ and $\mathrm{Fe}$ concentrations and total contents of liver and kidneys are presented in Tables 6 and 7 respectively. Over all, $\mathrm{Cu}$ supplementation had no significant effect on liver $\mathrm{Zn}$ concentration or content but after withdrawing the $\mathrm{Cu}$-supplemented diets liver $\mathrm{Zn}$ concentration decreased $(P<0.001)$ and total $\mathrm{Zn}$ increased $(P<0.05)$. Liver Fe concentration and total content were significantly increased by added $\mathrm{Cu}$ but after 2 weeks withdrawal of these diets only those birds which had previously been receiving $2000 \mathrm{mg}$ added $\mathrm{Cu} / \mathrm{kg}$ still showed liver Fe concentrations significantly higher $(P<0.00 \mathrm{I})$ than the control treatment.

Kidney $\mathrm{Zn}$ concentrations were unaffected by added $\mathrm{Cu}$ and length of time of withdrawal of this added $\mathrm{Cu}$ but there was a diet $\times$ time interaction $(P<0.0 \mathrm{I})$. Total kidney $\mathrm{Zn}$ was decreased by $\mathrm{Cu}$ supplementation of the diet and after 2 weeks of withdrawal of $\mathrm{Cu}$ from the diet the kidney total $\mathrm{Zn}$ of the hens offered the two highest levels of added Cu was restored to a value similar to that of the control. 
Table 7. Total zinc and iron contents $(\mu \mathrm{g})$ of the livers and kidneys of mature, female domestic fowl after withdrawal of Cu-supplemented diets

(Mean values for five observations)

\begin{tabular}{|c|c|c|c|c|c|c|c|c|c|c|}
\hline & \multicolumn{5}{|c|}{$\begin{array}{l}\text { Length of time after withdrawal of added } \mathrm{Cu} \\
\text { (weeks) }\end{array}$} & \multicolumn{4}{|c|}{$\begin{array}{c}\text { Statistical } \\
\text { significance of effect }\end{array}$} \\
\hline & & 0 & 2 & 4 & 6 & 8 & SEM & Diet & Time & Diet $\times$ time \\
\hline $\begin{array}{l}\text { Total } \\
\text { liver } \mathbf{Z n}\end{array}$ & $\begin{array}{r}0 \\
500 \\
1000 \\
2000\end{array}$ & $\begin{array}{r}1377 \\
1148 \\
810 \\
669\end{array}$ & $\begin{array}{l}1302 \\
1481 \\
1414 \\
1068\end{array}$ & $\begin{array}{l}1137 \\
1233 \\
1247 \\
1435\end{array}$ & $\begin{array}{l}1313 \\
1243 \\
1342 \\
1247\end{array}$ & $\begin{array}{l}1060 \\
1277 \\
1302 \\
1191\end{array}$ & $140 \cdot 1$ & $\mathbf{N S}$ & $*$ & NS \\
\hline $\begin{array}{l}\text { Total } \\
\text { liver Fe } \dagger\end{array}$ & $\begin{array}{r}0 \\
500 \\
1000 \\
2000\end{array}$ & $\begin{array}{c}2673 \\
(3.427) \\
3715 \\
(3.570) \\
4266 \\
(3.630) \\
3990 \\
(3.601)\end{array}$ & $\begin{array}{c}3148 \\
(3.498) \\
3112 \\
(3.493) \\
3342 \\
(3.524) \\
5635 \\
(3.751)\end{array}$ & $\begin{array}{c}3141 \\
(3.497) \\
3608 \\
(3 \cdot 557) \\
3350 \\
(3.525) \\
5310 \\
(3 \cdot 725)\end{array}$ & $\begin{array}{c}2972 \\
(3 \cdot 473) \\
3274 \\
(3 \cdot 515) \\
2945 \\
(3 \cdot 469) \\
3126 \\
(3 \cdot 495)\end{array}$ & $\begin{array}{c}2582 \\
(3.412) \\
3013 \\
(3.479) \\
2594 \\
(3.414) \\
3097 \\
(3.491)\end{array}$ & $(0.0670)$ & $* *$ & $*$ & NS \\
\hline $\begin{array}{l}\text { Total } \\
\text { kidney } \mathbf{Z n}\end{array}$ & 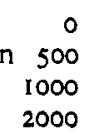 & $\begin{array}{l}240 \\
224 \\
162 \\
139\end{array}$ & $\begin{array}{l}278 \\
264 \\
234 \\
219\end{array}$ & $\begin{array}{l}260 \\
263 \\
269 \\
251\end{array}$ & $\begin{array}{l}262 \\
259 \\
271 \\
237\end{array}$ & $\begin{array}{l}249 \\
250 \\
273 \\
251\end{array}$ & $16 \cdot 2$ & $* *$ & $* * *$ & * \\
\hline $\begin{array}{l}\text { Total } \\
\text { kidney Fe }\end{array}$ & $\begin{array}{r}0 \\
500 \\
1000 \\
2000\end{array}$ & $\begin{array}{l}508 \\
55 \mathrm{I} \\
486 \\
454\end{array}$ & $\begin{array}{l}567 \\
607 \\
580 \\
577\end{array}$ & $\begin{array}{l}537 \\
560 \\
636 \\
743\end{array}$ & $\begin{array}{l}665 \\
680 \\
604 \\
617\end{array}$ & $\begin{array}{l}458 \\
474 \\
501 \\
504\end{array}$ & $63 \cdot 3$ & NS & $* *$ & NS \\
\hline
\end{tabular}

NS, not significant.

* $P<0.05, \quad * * P<0.01, \quad * * * P<0.001$.

+ Analysis of variance carried out using log transformations. The mean values presented are the antilogs of the mean of the $\log$ transformations. The values in parentheses are the means of the log values.

Supplementation of the diet with $2000 \mathrm{mg} \mathrm{Cu} / \mathrm{kg}$ significantly increased kidney Fe levels $(P<0.001)$ but after 2 weeks withdrawal of added $\mathrm{Cu}$ from the diets the Fe levels had significantly decreased $(P<0.001)$ and were no longer statistically different from those of the other treatments. $\mathrm{Cu}$ supplementation did not affect total kidney Fe but total kidney $\mathrm{Fe}$ increased for up to 6 weeks after $\mathrm{Cu}$ withdrawal.

\section{DISCUSSION}

The losses in body-weight and the decreases in food intake and egg production with the high levels of added dietary $\mathrm{Cu}$ were expected from previous findings (Jackson, 1977; Stevenson \& Jackson, I980). The recovery from body-weight loss and the increases in food intake and egg production after removal of the $\mathrm{Cu}$-supplemented diets are rather similar to the observations of Griminger ( 1977 ). The effect of $\mathrm{Cu}$ on the reproductive system was readily reversible and, in fact, the egg-laying capacity of the hens previously given $2000 \mathrm{mg}$ $\mathrm{Cu} / \mathrm{kg}$ was fully restored after 6 weeks on the control diet. The effect on egg production was probably due to the low nutrient intakes resulting from the greatly-reduced food intake of the birds offered the high-Cu diets.

The fact that the intake of high levels of $\mathrm{Cu}$ by the hens had no significant effect on $\mathrm{Hb}$, PCV, serum Cu and AAT (Table 2) suggests that the hen has a remarkable ability to adapt to high $\mathrm{Cu}$ intakes. This characteristic has been observed before for the mature, domestic fowl (Jackson, 1977; Stevenson \& Jackson, 1980). The lack of effect of high levels of dietary 
$\mathrm{Cu}$ on kidney fresh weight per unit body-weight can be taken as a further indicator of the ability of the domestic fowl to adapt to a high $\mathrm{Cu}$ intake.

The significant reductions in liver, oviduct and ovary fresh weights, expressed as $\mathrm{g} / \mathrm{kg}$ body-weight, in response to $\mathrm{Cu}$ supplementation (Table 3), were to be expected since similar results have previously been reported (Jackson, 1977; Jackson et al. 1979; Stevenson \& Jackson, 1980). The interesting novel information shown by the present work is the rapid restoration of the weights of these tissues to near control values and the accompanying return to normal function of the reproductive system as assessed by egg production.

Pathological effects on the gizzard in response to high dietary $\mathrm{Cu}$ have been reported in the broiler (Fisher et al. 1973; Poupoulis \& Jensen, 1976). In the laying hen the feeding of diets containing up to $800 \mathrm{mg}$ added $\mathrm{Cu} / \mathrm{kg}$ failed to cause gizzard lesions although gizzard weight was increased (Jackson et al. 1979) but feeding higher levels of added $\mathrm{Cu}$ caused thickening and damage to the gizzard lining and an associated weight increase (Stevenson \& Jackson, I980). The sex difference in gizzard tolerance to dietary Cu (Fisher et al. 1973) may partially explain the lack of severe erosion found in the laying hen in previous experiments reported from this laboratory.

The significant increase of bile duct weight caused by $\mathrm{Cu}$ supplementation of the diet and the subsequent decrease when the control diet was given indicates that the bile duct is an important pathway of $\mathrm{Cu}$ excretion. This substantiates the observations of Beck (1961) who found that after injection of $\mathrm{CuSO}_{4}$ the biliary $\mathrm{Cu}$ level of cockerels was substantially increased. The lack of response of serum $\mathrm{Cu}$ to high levels of $\mathrm{Cu}$ ingestion in the mature hen is probably related to the fact that the bile duct is an important pathway of $\mathrm{Cu}$ excretion.

The functions of the caeca in the digestive processes of the domestic fowl are not clearly understood. Beck (1961) reported that the caeca had some significance in Cu excretion by the cockerel. King (1972) found an effect of dietary $\mathrm{Cu}$ on caecal length per unit bodyweight in broiler chicks. An increase was observed in the male and a decrease in the female. $A$ decrease in caecal weight per unit body-weight and in weight per unit length has been found for ducklings (King, 1975). The lack of effect in the present experiment indicates that the mature female domestic fowl shows a response which is different from that of the immature bird.

The significant decrease in liver lipid concentration with added dietary $\mathrm{Cu}$ is in agreement with the findings of Jackson et al. (1979) and Stevenson \& Jackson (1980) and is obviously associated with depression of fatty acid and lipid synthesis in the liver (Ranney \& Chaikoff, I95I; Goodridge, I968; O'Hea \& Leveille, I969).

The increases in the concentration and total $\mathrm{Cu}$ content of the livers of birds given $\mathrm{Cu}$ supplemented diets were expected in the light of previous results (Jackson, I977; Jackson et al. 1979; Stevenson \& Jackson, 1980). A most interesting aspect of the present work was the rapidity with which $\mathrm{Cu}$ was eliminated from the liver when the birds were given control diets. After 2 weeks withdrawal of $\mathrm{Cu}$-supplemented diets, the mean $\mathrm{Cu}$ concentration and total $\mathrm{Cu}$ content of the livers of birds subjected to the highest level of $\mathrm{Cu}$ supplementation were only $16 \%$ and $50 \%$ respectively of the value obtained after 8 weeks of $\mathrm{Cu}$ treatment. After 4 weeks of $\mathrm{Cu}$ depletion the corresponding values were approximately $3 \%$ and $11 \%$. This shows that the domestic fowl has a mechanism for the rapid withdrawal of $\mathrm{Cu}$ from the liver. The lack of effect of $\mathrm{Cu}$ supplementation on kidney $\mathrm{Cu}$ in the present work and the relatively small effect noted previously (Jackson et al. 1979; Stevenson \& Jackson, 1980) indicates that the kidney is not significantly involved in $\mathrm{Cu}$ storage or excretion.

Significant increases in the $\mathrm{Cu}$ concentration and the total $\mathrm{Cu}$ present in the caeca as a consequence of feeding $\mathrm{Cu}$-supplemented diets as found in the present experiments have also been observed in the broiler (Fisher et al. 1973; Jensen \& Maurice, 1978). The caecal contents also showed the physical characteristics, namely the dark colour and pastiness, 
as described by Jensen \& Maurice (1978). After 2 weeks withdrawal of the $\mathrm{Cu}$-supplemented diets, the over-all mean caecal $\mathrm{Cu}$ concentration and content were less than $30 \%$ and $4 \%$ respectively of the values found after giving $\mathrm{Cu}$-supplemented diets for 8 weeks. The concentration and total $\mathrm{Cu}$ contents tended to remain fairly constant thereafter. There is no obvious explanation as to why mean $\mathrm{Cu}$ concentrations and contents rose after 8 weeks.

Although the concentration and total $\mathrm{Zn}$ content of the livers were unaffected by diet, nevertheless the values for zero time of $\mathrm{Cu}$ withdrawal show an increase in $\mathrm{Zn}$ concentration and a decrease in total $\mathrm{Zn}$ content. This agrees with the results of Stevenson \& Jackson ( 1980 ). The mean liver $\mathrm{Zn}$ concentration decreased by approximately $40 \%$ over the 8 -weeks withdrawal period. The total $\mathrm{Zn}$ content increased by $21 \%$ over this period this being a reflection of the large increase in liver weight. The increases in liver Fe concentration and total $\mathrm{Fe}$ as a result of $\mathrm{Cu}$ supplementation are in agreement with previous findings from this laboratory (Jackson et al. 1979; Stevenson \& Jackson, 1980). The reduction in liver Fe on withdrawal of the dietary $\mathrm{Cu}$ appeared to be directly related to the reduction in liver $\mathrm{Cu}$.

As for the liver, the tendency was for $\mathrm{Cu}$ supplementation to result in an increase in the kidney $\mathrm{Zn}$ concentration and a decrease in total content. This effect on total kidney $\mathrm{Zn}$ content was also reported by Stevenson \& Jackson (1980). In the present experiment kidney Fe concentration was increased by the highest $\mathrm{Cu}$ supplement whereas Stevenson \& Jackson (1980) did not find that Fe concentration was significantly increased although there was a trend towards an increase with increasing $\mathrm{Cu}$ supplementation. Total kidney Fe was unaffected by $\mathrm{Cu}$ treatment but after withdrawal of added $\mathrm{Cu}$ there was a significant increase in total kidney $\mathrm{Fe}$ and a significant decrease in Fe concentration, which is rather surprising since kidney weight was unaffected by withdrawal of the $\mathrm{Cu}$-supplemented diets.

The authors thank Dr D. Kilpatrick for statistical analyses and Mr W. Graham, Mr G. McC. Kirkpatrick and Mrs R. Park for technical assistance.

\section{REFERENCES}

Beck, A. B. (1961). Aust. J. agric. Res. 12, 743.

Fisher, C., Laursen-Jones, A. P., Hill, K. J. \& Hardy, W. S. (1973). Br. Poult. Sci. r4, 55.

Goodridge, A. G. (1968). Am. J. Physiol. 214, 897.

Griminger, P. (1977). Poult. Sci. 56, 359.

Jackson, N. (1977). Br. J. Nutr. 38, 93.

Jackson, N., Stevenson, M. H. \& Kirkpatrick, G. McC. (1979). Br. J. Nutr. 42, 253.

Jensen, L. S. \& Maurice, D. V. (1978). Poult. Sci. 57, 166.

King, J. O. L. (1972). Br. Poult. Sci. 13, 61.

King, J. O. L. (1975). Br. Poult. Sci. 16, 409.

O'Hea, E. K. \& Leveille, G. A. (1969). Comp. Biochem. Physiol. 30, 149.

Poupoulis, C. \& Jensen, L. S. (1976). Poult. Sci. 55, I1 3.

Ranney, R. E. \& Chaikoff, I. L. (195I). Am. J. Physiol. 165, 600.

Stevenson, M. H. \& Jackson, N. (1980). Br. J. Nutr. 43, 205. 